\title{
The effect of board characteristics and audit committee characteristics on audit quality
}

\author{
Dheyaa Zamil Khudhair ${ }^{a^{*}}$, Firas Khudhair Abbas Al-Zubaidia and Ali Abdulhussein Raji ${ }^{\mathrm{a}}$
}

${ }^{a}$ College of Administration and Economics, University of Al-Qadisiyah, Iraq

\section{CH R O N I C L E}

Article history:

Received: October 2, 2018

Received in revised format: No-

vember 15,2018

Accepted: November 24, 2018

Available online:

November 24, 2018

Keywords:

Audit Quality

Audit Committee

Audit Committee independence

Audit Committee competencies

Board Size

Iraq

\section{A B S T R A C T}

\begin{abstract}
The issues of audit quality and audit committee have received huge consideration from the auditing profession, the general public population and the government controllers particularly after the prominent corporate outrages in firms like Enron, Global Crossing, Tyco, and WorldCom. These concerns discourage investors to invest in foreign and local businesses. The primary objective of the current study is to explore the impact of internal and external governance mechanisms such as board size, audit committee independence, audit committee expertise, and audit committee meetings on the quality of audit in selected firms. The study is carried out on a sample of Iraqi nonfinancial firms. The dependent variable is the audit quality measured as a dummy variable and it receives 1 if a firm receives audit services of big five auditing firms and zero, otherwise. To achieve the research objectives the study uses logit regression technique. The results indicate that there was a positive relationship between audit quality and the percentage of non-executive directors in the audit committee. The findings of the current study will be helpful for policymakers, researchers, accountants, financial experts, and audit practitioners in understanding the importance of the concept of audit quality and the key factors which affect the audit quality of any non-financial firms in Iraq.
\end{abstract}

2019 by the authors; licensee Growing Science, Canada

\section{Introduction}

It was observed that audit committee trustees neglected to successfully oversee managers (Al- Matari et al., 2012). Vicknair et al. (1993) and Fodio et al. (2013) expressed that with a specific end goal to work successfully, audit committees should not have cordial relationship with inside management, this would create differentiation between inside management and independent board of audit committee. It would permit the audit committee and the external auditor to be independent and effective from companies' executives. For instance, Enron controlled its financial proclamations through off-balance sheet financing. The committee was not able to uncover the contorted proclamations on account of the absence of board autonomy from senior executives (Deakin \& Konzelman, 2004). Audit quality is a reliable evidence amongst the most basic issues in audit practice. A couple of individuals and social affairs; both inside and outside provide different methods for auditing business information (IAASB 2011). Audit quality can be conceptualized as a theoretical continuum moving from low to high audit quality. Audit disappointments clearly happen on the lower end of the quality continuum, thus a decent beginning stage in pondering audit quality is to solicit what the rate of outright audit disappointment. An * Corresponding author.

E-mail address: dhiaa.zamil@qu.edu.iq (D. Z. Khudhair) 
audit disappointment happens under two circumstances: when normal sound accounting guidelines are not authorized by the auditor called Generally Accepted Accounting Principles (GAAP failure) and when an auditor neglects to issue an altered or qualified audit report in the proper circumstances (audit report disappointment). In both cases, the audited financial proclamations are conceivably misleading to clients and stakeholders. There are various causes which can influence the high quality of the audit. Financial Reporting Council (FRC) in 2008 recommends them as: (a) components outside the control of the auditors, (b) convenience of the audit reporting (c), the culture surrounds the audit firm both inside and outside, (d) the audit process and (e) personal qualities and skills characteristics of audit accomplices and staff. The GAAP traces critical components, for example, ability, autonomy, and activity of due expert to the nature of the external auditor's execution. Audit quality assumes a vital part in keeping up an effective business sector environment, a free quality audit supports trust in the validity and honesty of financial articulations which is the key for well-working markets and upgrades financial performance.

Sound audits can fortify strong risk management, internal control at firms and corporate governance, along these lines adding to financial performance. High quality outside auditing is a focal part of wellworking capital markets. The accounting literature concentrates on two principal strengths. Under the main thought process, if auditors are legitimately obligated for audit disappointments, then they have a motivator to deliver high quality to avoid the costs of litigation. The insurance part emerges on the grounds that investors consider larger audit firms as these organizations can better meet investors' lawful cases, in this manner giving financial resources plan of action against poor audit quality. Additionally, the reputational incentives motivate, accounting firms have to avoid audit disappointments since audit quality is profitable for customers. Customers' imperfection to different auditors when an audit company reputation for quality turns out to be more awful (Skinner \& Srinivasan, 2012).

Though, the Big Four firms as characterized in Business Week (Gerdes, 2009) are Deloitte and Touche, Ernst and Young, PricewaterhouseCoopers (PwC), and KPMG which are positioned top among 50 open and legislative organizations. The statutory audit can fortify certainty in light of the fact that auditors are relied on to give an outer, target sentiment on arranging and presentation of financial verbalizations. Auditors ought to be free in the notions they express, while the work they have to set up their appraisals is exceedingly dependent on and set up in this present reality and may get the opportunity to be attempting in some business circumstances, for instance, the cement business. It is against this connection that the investigation work is finished.

\section{Literature review}

\subsection{Audit Quality}

Audit quality broadly refers to the services performed by the auditors engaged by the client firms. Firms demand higher quality audit because of the standard and experience they have acquired. Hiring audit quality would attract more investors and picture the performance of the organization. Hence, stakeholders and investors will have confidence and trust in the company engaged in higher audit quality because of the reputation and the experiences that accounting firms with audit quality have gained.

Higher audit quality is proactively providing assurance to the investors, deliver a service that goes beyond the simple audit and creates an avenue for consulting (Behn et al., 1997). Richard (2006) argued that achieving higher audit quality should be balanced among the relationships among employees, professionals and independence and competence of accounting firms. Lee et al. (1995) suggested that accounting firms cannot choose to be independent unless it is competent. Clients observed that larger accounting firms are independent and competent in international markets and smaller accounting firms 
have low and incompetence experiences in local markets (Louis, 2005). The competence of Big accounting Firms has made them involve and contribute in standard setting such as Anglo-Saxon countries (Brown, 2004). According to Nobes and Parker (2008), an accounting system in Ministry of Finance, China was developed by Deloitte as one of Big accounting Firms due to the independence and competence in international accounting standards board (IASB). Adequate training and competence in auditing are evidences of high-quality auditing for the investors because the result is prepared by professional accounting firms (Gul et al., 1994).

In addition, the independence of an auditor is indicated as a factor that determines the accounting firms size (Abu Bakar et al., 2005). Mautz and Sharaf (1961) revealed that large accounting firms can be perceived through research facilities, independence, financial resources, qualified experience, and training staffs. However, small accounting firms with a single client may increase the risk of dependence due to the small portfolio of the client compared with those of Big accounting firms (Mautz \& Sharaf, 1961). Large accounting firms protect their independence and reputation because of large client portfolio the firms audit (DeAngelo, 1981).

Incompetence and low-experiences staff or any elements that can hinder the quality of independent auditors may lower the standard of quality of audit (Watts \& Zimmerman 1981). Palmrose (1988) revealed audit quality as the levels of affirmations. More elevated amounts of affirmations (i.e. the probability of financial statements should comprise zero misstatements or fewer number of mistakes) have relationships with the standard audit quality at the way around. Audit failures have been created as the basis of this definition (in a situation where the issue of misstatement appears, or auditor fails to recognize inconsistent materials) which need to be found in the legal process.

Francis (2004) described low quality as an audit failure which may bring about a few results such as regulatory authorizations, litigation rates, and business disappointment. According to Institute of Chartered Accountants in England and Wales (ICAEW) in (2002) as a regulator "audit quality as the best expectations that contain evidence, reliability, and appropriate expertise opinion, free and fair judgments have the quality of the audit." However, regulator agrees that independent auditors that provide adequate audit evidence have a higher quality service and can be relied on.

According to Francis (2004), audit quality is contrarily identified with non-fulfillment audit: the lower the nature of auditing, the higher the non-fulfillment rate. Regardless of the way that specialized qualities, for instance, an auditor's ability to distinguish and report mistakes, have been claimed as the characterizing parts of a quality audit. According to Duff (2004) audit quality is contained both specific quality and service delivering in terms of quality (the desires and client's satisfaction). Specialized quality contains ability, experience, skill, integrity and independence scales. However, advantage quality is depicted by responsiveness, feeling and the procurement of client services and Non-Audit Service (NAS). Audit quality is chosen by auditors' capacity to get ruptures of accounting norms and in this manner the auditors motivate to report such breaks i.e., audit quality could be the result of auditor capacity and freedom. According to DeAngelo (1981) huge enterprises are identified with higher audit quality as a result of their extra autonomous. For large auditors like Big Four firms, no individual or customer is monetarily fundamental in respect to the estimation of an identified audit disappointment. Besides, the Big Four industry has set up brand-name position and in this manner have motivators to shield their prestige by providing desire quality audit (Reichelt \& Wang 2010).

Early studies utilize the experience, information asymmetry, and service between the Big Four and Non- Big Four firms and demonstrate that Big Four industry performs audits of upper quality and are more extra moderate (Krishnan \& Visvanathan, 2008). Firms prefer towards name-brand (Big Four) auditors on the off chance that they are liable to extra agency clashes. Big Four auditors have a universal position and reveal commonly to have extra freedom than non-industry specialization auditors do. On 
the off chance that Big Four auditor's offer higher quality, the interest for their services should increase in the light of customers' organization issues (DeFond, 1992). PricewaterhouseCoopers (2002) contends that audit quality relies on a few elements together with auditors. Teoh and Wong (1993) see Big Four auditors as giving higher quality audit.

These arguments, therefore, recommend that auditors with industry experience observe misrepresentations and irregularities better than auditors with no industry experience. DeAngelo (1981) contends that firm size might be an intermediary for quality (auditor independence) since there is no single client is vital to a Big Four auditor and this protects their reputation (their whole clientele) for not misreporting. To realize high and reliable audit quality, Big Four firms tend to enroll people that are friendly and labile to government officials' authorities.

The work expertise in massive Big Four companies is so doubtless to "mold" auditors that end up being totally different from auditors in non-Big Four companies. As an alternative, those recruited by large four firms might have comparatively additional conservative personalities that additionally results in conservative audit outcomes. Evidence indicates that client of massive four audited firm preserves less irregular collections which means less forceful profit management conducts thus higher income quality.

According to Gottschalk (2011), the perspective of audit quality may be categorized into parts. The lawful perspective of auditing offers to a basic classification of either "audit disappointment" or "nonaudit disappointment". An audit disappointment happens if the auditor does not receive truth, Conversely, a "decent audit" or a non-disappointment is the one within which the auditor agrees to examine gauges and problems associated with the client's financial explanations at an acceptable level of audit risk. The audit quality has been characterized as a result of restrictive on the neighborhood of specific characteristics of auditors. According to Louis (2005) many components might empower nonBig Four firms to determine anomalies. Basu et al. (2001) specify the distinction between the Big Four versus Non-Big Four auditee earnings within the United States.

Collectively, it is advocated that audit quality may be a nonstop build that guarantees the high quality of financial statement with the standard expectations. Higher quality of audit enhances the quality of financial reporting in an exceedingly means of promoting the companies' image and this would create awareness to stakeholders and investors. Therefore, it denotes that audit quality serves as a yardstick for standard financial reporting. Effective communication and commitments between auditors and board audit committee are capable of increasing audit quality through active involvement. To sum up, audit quality broadly is referred to the independent, competence, mechanism, reputation which auditors implement in order to be recognized as an independent audit in providing a financial statement without qualified, error and unfair reports.

\subsection{Audit committee independence and audit quality}

Normally, an audit committee is simply referred to a constituted body that is giving authority and responsibility to oversee the financial reporting of a firm and report the findings to the top management for decision making. The committee is expected to provide an invaluable information and communicates to the board of directors of the firm. Also, the committee is responsible for mediating between the external and internal auditors and assist the board to ensure all the related issues on audit (Al-Matari et al., 2012). The Sarbanes Oxley (SOX) Act (2002) allocated particular obligations to the audit committee, it is the responsibility of the committee to oversight auditors work, compensate and resolve financial reporting. Audit committee likewise has the right to select or appoint independent advice and consultants (Klein, 2003). According to Cadbury (1992) greater part of non-executive directors ought to be autonomous of management and free from any business or other relationship which could tangibly meddle with the activity of their autonomous judgment, aside from their expenses and shareholding. In 
addition, SOX (2002) requires that all individuals from an audit committee should be autonomous of the companies' management as well as those who oversee the financial reporting processes and accounting procedures. Audit advisory group independent non-executive can possibly make a move identified with the outside auditors that may bring about a larger level of audit guarantee or scope. Any of the group that has freedom director as the head can endeavor to induce management to choose a more proficient auditor with more remarkable.

Beasley et al. (2000) found that organizations with inappropriate financial reports have less non- executives directors or independent committee than organizations with the proper benchmark. Abbott and Parker (2000) reported that organizations with audit boards of trustees contained autonomous nonexecutive directors that meet at any rate twice every year will probably choose from Big Four auditors when exchanging auditors.

Carcello and Neal (2000) found that fiscally troubled firms with the autonomous audit advisory group will probably get going-concern conclusions. Abbott and Peters (2004) found that organizations with audit advisory group autonomous are less inclined to encounter a fake and low audit quality. Zainal et al. (2009) found that a higher extent of free non-executive directors upgrades companies' execution, because of their differing foundation, properties, and qualities, which may enhance decision making forms. Non-executive directors are thought to be in a superior position than executives to satisfy their observing capacities since they are free and worried with keeping up their notoriety in the outside work market (Fama \& Jensen, 1983). The findings of Beasley et al. (2000), Carcello and Neal (2000, 2003) and Abbott et al. (2003) depend on an affirmation that audit group autonomous of management would not have an individual and/or financial reliance on management. The absence of freedom from the management may incidentally transform the individuals from the audit group into an expansion of the management group itself and this will crush the goal of having the audit advisory group in any case. There ought to be an expansive majority of independent or non-executives directors, audit group individuals that serve on the audit advisory group to improve firm value.

Agency theory predicts that, since gatherings impart less viable past a specific size, there is a pressure from self-serving managers or entrenched in principals to require audit committee adequacy. The suggestion is a backward relationship between audit committee independence and audit quality. The empirical research likewise reports clashing results concerning the relationship between audit committee independence and audit quality. A typical desire is that, the independent non-executive directors of the audit committee would guarantee better financial reporting (SEC 2003), and the desire is generally upheld by existing exact proof (Abbott et al., 2000 ). For instance, the independence of the board audit committee is another key trademark for powerful observing of the financial reporting process (Krishnan, 2005).

Eichenseher and Shields (1985) claimed that audit committee autonomous appoint Big Four auditors for audit quality contemplations as well as on the grounds that Big Firms auditors are fit for retaining a more prominent bit of potential prosecution misfortunes than non-Big firms auditors. Similarly, Bronson et al. (2009) reported that advantages of audit committee freedom are reliably accomplished just when the audit advisory board is totally autonomous.

Kent et al. (2010) observed that higher audit advisory group freedom is connected with higher accumulations quality and consequently enhanced financial reporting quality. Anderson et al. (2004) provides some evidence that completely autonomous audit board are connected with an essentially bringing down the expense of obligation. According to Abbott and Parker (1999, 2000), audit board which meets minimum levels of both independent and activity will probably draw in higher quality outside auditors. 
The responsibility of the audit board of trustees can be analyzed in three perspectives: the size, the frequency of its meetings and the duties it has to perform. The activity of audit advisory group autonomous non-executives can be characterized into two routes: the external audit and oversight of the financial statements. This study concentrates on the two since they are the most important area that provides the reputation of Big Firm \& non-Big Firm and organization inputs (Audit committee) (Wolnizer, 1995). Since audit quality is characterized as far as the probability of distinguishing and reporting a material financial misquote (DeAngelo, 1981), by augmentation, the issue of the independent audit committee has relationship with the level of higher financial reporting quality.

Byrd and Hickman (1992) guaranteed that the more noteworthy proportion of non- executives directors, the better the share trading system reaction to a company's delicate offer for different high quality firms. Bonn (2004) found that there was a certain relationship between the proportion of non-executives directors and organization execution. Ameer et al. (2010) presumed that organizations with outside directors are required to have a superior quality contrasted with those organizations that have a large number of executives internal manager and associated non-executives directors in the audit advisory group.

Sun (2013) discovered a negative and significant on the relationship between audit industry specialization and audit committee independence. According to Cohen et al. (2011), audit committee independent is significant in guaranteeing the respectability of the financial reporting process. This demonstrates that non-executive's audit committee member is likely to be more efficient in monitoring audited financial statement.

H1: There is a positive relationship between non-executive directors of the audit committee and audit quality.

\subsection{Audit committee expertise and audit quality}

The meaning of current pertinent financial capability is questionable and there has not been an unmistakable understanding of this necessity. One proposed definition gives in the SOX is introduced as: "A financial master is any part who has the training or experience of a public accountant, principal accounting officer of an issuer, principal financial officer, auditor or has been in a position requiring the comprehension of sound accounting guidelines and financial articulation involvement in the arrangement and auditing of financial proclamations of practically identical issuers, involvement in the use of such standards regarding the representing appraisals, understanding of audit committee functions, accruals and reserves, and experience with internal accounting" (Dalley, 2003).

Financial knowledge decreased extortion in corporate financial reporting. A formal acknowledgment of this necessity was recently made in the U.S. with the passing of the SOX (2002) which requires every public recorded organization to uncover regardless of whether it has a financial master in the audit group. Accounting firms by Pricewaterhouse Coopers (1999) and SEC (2003) regulators contended that financial mastery is fundamental to guarantee that the audit committee satisfies their essential obligations of regulating the financial reporting and upgrading financial reporting quality.

Jaime and Micheal (2013) claimed that the financial master of the audit board is essential since the audit advisory group is in charge of the financial reporting process and audit quality. They explained that audit boards with financial ability can offer huge benefits for the stakeholders since the financial information is the favorable position of distinguishing any control. DeFond and Francis (2005) found that market contestants respond decidedly to the arrangement of an audit advisory group with a financial master in accounting, however, no response is noted for audit advisory group with non-accounting 
financial capability. This is because of the way that the arrangement of council individuals with accounting financial knowledge enhances the oversight capacity of the advisory group and therefore gives a tenable sign to the investors that the organizations seek to a higher audit quality and financial reporting. Financial reporting quality is better when financial knowledgeable part is a piece of the audit group (DeZoort et al., 2001, 2003). McDaniel et al. (2002) observed that specialists tend to concentrate more on recurring, less-unmistakable issues, while financial literates concentrated more on non-repeating, conspicuous issues. Lo et al. (2010) noted that the existence of financial expertise on the audit advisory had a significant positive relationship with financial reporting quality. Defond et al. (2005) in their study identified that the business sectors show partiality just to financial reporting with an accounting experience or skill on the audit committee. Also, Krishnan and Visvanathan (2008) confirmed a solid positive relationship between earnings quality and accounting financial knowledge. Dhaliwal et al. (2010) demonstrated that accounting financial knowledge is connected with less profit management. Davidson et al. (2004) found that there was a positive relationship between financial performance and financial proficiency or knowledge audit committee members. Sun (2013) found that the market sector responds positively to financial specialists on audit committee after SOX. This will help mitigate some of the agency problems that cause low audit quality. Based on the various theoretical arguments, this study proposes that:

$\mathrm{H} 2$ : There is a positive relationship between the financial expertise of non-executive directors in the audit committee and audit quality.

\subsection{Board size and audit quality}

Board size or the quantity of executives on board is an imperative element in the viability of the board. The increment in board size would enhance organizations' board adequacy to bolster the management in lessening agency cost that came about because of poor management and would prompt better financial results (Jensen \& Meckling, 1976). Jensen (1993) claimed that when the number of board size is more than seven or eight it is likely to be difficult to coordinate or be effective. According to Raheja (2005) the directors of the board have two functions: Key relevant to monitor and advise the board. Cheng (2008) claimed that the high quality of financial statement is related to the commitment of a larger board size. The direction of impact is highly dependent on the experience and knowledge of the members of the board, this significantly depends on the size of the board because if the board is huge it is expected that they would have more expertise as compared with a small board. Empirical findings show that the board size does matter (Zona et al., 2013), because it impacts monitoring, controlling and decision making in the company. Indeed, McDonald and Westphal (2013) argued that larger boards are capable of giving more time and efforts to check the management actions and vice versa.

Contrary to this, it is also argued that the advantages of superior control of management by a huge board nullifies the disadvantages that are caused because of difficulty in coordination, communication and decision making. The study conducted by Eisenberg et al. (1998) also supports the argument that if the board were small the performance of the board would be better. There is no consensus in the literature about board size; whether a large number or a smaller board of directorate is better. This is because a small group can easily reach a conclusion (Balakrishnan et al., 2014) and to engage in genuine interaction and debate. Hutchinson et al. (2015) argued that the benefit of higher level monitoring by a huge board may be nullified because of poor decision making by a large board. On the other hand, small boards are believed to alleviate the processing problems and hence become more effective (Zona et al., 2013). Furthermore, a large board widens the range of ideas to resolve the issues (Xie et al., 2003).The capacity of the board to monitor the management is enhanced by adding more directors. According to Nicholson and Kiel (2003) larger board size influence positively on audit quality. Hence, the large board sizes are definitely important, previous research has proved that most organizations 
with small board sizes have effective contributions because of easier communication between the manager and directors. Based on the various theoretical arguments, this study proposes that:

H3: There is a positive relationship between board size and audit quality.

\subsection{Audit committee meetings and audit quality}

Audit committee activity plays a vital part in managing and observing the financial reporting process. It is contended that the recurrence of groups of audit committee meeting is the key determinant of its adequacy and a vital part in tending to critical organization issues connected with management force vesting through large ownership (Sharma et al., 2009). The Smith committee (2003) contends that audit committee meetings are at the heart of the work and the groups must have the meeting which defines their duties and responsibilities. The improvement and transparency of higher audit quality are associated with the regular meeting of audit committees (Bryan et al., 2004). Bronson et al. (2006) found that there is a possibility of a high level of quality as well as audit committee meet regularly while the chance of restatements or reporting problems decreases (Abbott et al., 2004). Most of the information on the audit committee meeting was extracted through the company's corporate governance annual reports. In the annual report, it was revealed that the minimum audit committee meeting should be two in a year. Based on the various theoretical arguments, this study proposes that:

H4: There is a positive relationship between audit committee meetings and audit quality.

\section{The proposed study}

Considering the categorical nature of depending viable the logit regression model is used to achieve the research objective of the currents study. The logit regression model is used on the basis of recommendations of Hoechle (2007).

$$
\begin{aligned}
A U D Q U A L= & \alpha 0+\beta 1 N E D A C+\beta 2 \text { FENEDAC }+\beta 3 \text { BDSIZE }+\beta 4 A C M E+\beta 5 R O A+ \\
& \beta 6 \text { COMPSIZE }+\beta 7 C F O+\beta 8 \text { LEVERAGE }+\varepsilon .
\end{aligned}
$$

Notes: AUDIT QUALITY $=1$ if the client is engaged with the service of Big Four auditor in financial year, and 0 , otherwise, NEDAC = the percentage of non-executive directors in the audit committee, FENEDAC is a Dummy Variable is equal to 1 if at least one of non-executive directors in the audit committee has accounting knowledge, financial management or able to read financial statement, and 0 otherwise, BDSIZE $=$ the total number of directors serving on the board of directors, COMPSIZE $=$ the natural log of total assets, $\mathrm{ROA}=$ earnings before interest and tax divided by total asset, $\mathrm{ACME}=$ number of audit committee meetings held during the year, $\mathrm{CFO}=$ cash flow from operation scaled by lagged total asset and LEV $=$ total debt $/$ total assets.

\section{Table 1}

The summary of descriptive statistics for sample firms

\begin{tabular}{lccccc}
\hline VARIABLE & OBS & MEAN & STD. DEV. & MIN & MAX \\
\hline Big 4 & 168 & 0.64 & 0.48 & 0.14 & 1 \\
NEDAC & 168 & 0.42 & 0.50 & 0.17 & 0.75 \\
FENEDAC & 168 & 0.58 & 1.80 & 5 & 1 \\
BDSIZE & 168 & 8.94 & 0.66 & 5.77 & 13 \\
LogCOMPSIZE & 168 & 7.28 & 0.11 & -0.38 & 0.99 \\
ROA & 168 & 0.07 & 0.97 & 2 & 7 \\
ACME & 168 & 3.81 & 3020000 & -2770000 & 27500000 \\
CFO & 168 & 9274787 & 16.05 & 0 & 72.17 \\
LEV & 168 & 23.83 & & & 0.6 \\
\hline
\end{tabular}

It is revealing that 64.3 percent of non-financial sector in this study was engaged with Big Four firm while the remaining 35.7 percent used non Big Four firms. On average, the number of non-executive directors in audit committee was 0.42 with a minimum of 0.17 directors and maximum of 0.75 directors. 
The average 58 percent of the financial expertise of non-executive directors of audit committee were accounting, or financial expert with a range between 0 and 1 percent. This study also discovered that the average board size of directors serving in firm was 8.94 with the recorded a minimum, maximum, and standard deviation of 5,13 , and 1.80 , respectively. The mean of the company size is 7.28 while the maximum and minimum are 8.99 and 5.77 respectively with a standard deviation of 0.66 . The result on the return on assets yields a mean of 0.07 with a minimum of -0.38 , maximum 0.61 and standard deviation of 0.11 . Result found that the average held of the audit committee meeting during the year was 3.81 with a minimum 2 and maximum of 7 . In addition, the cash flow recorded a figure of 9274787 , $-2.7770,2.7500$ and 3.0200 respectively for mean, minimum, maximum and deviation while the mean of the leverage is 23.83 percentages while the minimum and maximum are 0 and 72.17 respectively with a deviation of 16.05 .

Table 2

Correlation

\begin{tabular}{|c|c|c|c|c|c|c|c|c|c|}
\hline & & 1 & 2 & 3 & 4 & 5 & 6 & 7 & 8 \\
\hline NEDAC & 1 & -0.198 & 1 & & & & & & \\
\hline FENEDAC & 2 & 0.156 & -0.193 & 1 & & & & & \\
\hline $\operatorname{logBDSIZE}$ & 3 & -0.066 & 0.009 & 0.188 & 1 & & & & \\
\hline logCOMPSIZE & 4 & 0.344 & 0.119 & 0.151 & 0.366 & 1 & & & \\
\hline ROA & 5 & -0.045 & 0.02 & -0.109 & -0.073 & -0.12 & 1 & & \\
\hline $\mathrm{ACM}$ & 6 & 0.016 & -0.027 & 0.04 & 0.206 & -0.035 & 0.116 & 1 & \\
\hline $\mathrm{CFO}$ & 7 & 0.188 & 0.109 & -0.019 & 0.121 & 0.487 & 0.065 & -0.058 & 1 \\
\hline LEV & 8 & -0.212 & -0.023 & -0.048 & -0.07 & -0.067 & 0.062 & -0.131 & -0.079 \\
\hline
\end{tabular}

Correlation explains the association between the audit committee and audit quality. Correlation ranges from $(+1)$ to $(-1)$. When the correlation between two variables is +1 , it implies a perfectly positive association and when it is -1 , it implies a perfect negative association. The results of the study are presented in Table 3. According to the results, the regression results have shown a great deal of agreement with the hypothesized results.

Table 3

The summary of Logit regression

\begin{tabular}{lllll}
\hline & Coef & RobustStd. & $Z$ & VIF \\
\hline NEDAC & 0.546 & 0.163 & $3.35^{*}$ & 1.07 \\
FENEDAC & 0.232 & 0.243 & 0.95 & 1.07 \\
logBDSIZE & 1.964 & 0.724 & $2.71^{* * *}$ & 1.25 \\
logCOMPSIZE & 0.957 & 0.229 & $4.17^{* *}$ & 1.58 \\
ROA & -0.051 & 0.202 & -0.25 & 1.07 \\
ACM & 0.111 & 0.537 & 0.21 & 1.10 \\
CFO & 0.000 & 0.000 & 1.60 & 1.37 \\
LEVERAGE & -0.018 & 0.007 & $-2.51^{* *}$ & 1.04 \\
Cons & -0.879 & -0.879 & -0.49 & \\
\hline
\end{tabular}

No of Obs 168

Prob $>$ Chi-Square $\quad 0.0000$

Adjusted-R $^{2} \quad 0.2517$

Mean VIF $\quad 1.20$

Notes: Audit quality $=1$ if the client engages the service of Big 4 auditor in a financial year, and 0 otherwise. * Significant at $\mathrm{p}<0.01$ or better. (1-tailed), ${ }^{*}$ Significant at $\mathrm{p}<0.05$ or better. (1-tailed) and $* * *$ Significant at $\mathrm{p}<0.10$ or better. (1-tailed).

\section{Conclusion and discussion}

The relationship between AUDIT QUALITY, and NEADAC is positive and significant at 1 percent. This result is in line with the findings of previous studies. Adegbite (2015) claimed that many CEOs, serving in another company and upon their retirement, are appointed as non-executive directors in other companies which lead to retain strong influences on behalf of their successors and less audit quality. Ahunwan (2003) stated that a strong minority or majority owners of companies' shares were described 
as CEO's property. Al-Mudhaki and Joshi (2004) emphasized that research on audit committee in developing countries could not have met applicable definitions. Mautz and Neumann (1970) posit that the association between management of companies and audit committee had long been excessively close making it impossible to guarantee an autonomous supervision of the audit quality. Bassett (1998) denoted that performance evaluation and self-assessment would be needed for the audit committee which reviews the performance of (internal) evaluation non-executive directors and audit quality (Big Four \& non-Big Four). Though the issue of board evaluation is not popular in Iraq and provides a clear picture of performance of the individual members whether they are consistent with the objectives and responsibilities of setting the audit committee. The hypothesized results state a positive relationship between the financial expertise of non-executive directors audit committee (FENEDAC) and AUDIT QUALITY. However, as found in the study, the relationship is positive but not significant in this study with indicator $p>10$. This, therefore, it implies that the insignificant of the financial expertise of nonexecutive directors audit committee may be the effect of their important input if some of the FENEDAC serve duality committee (i.e. more than one committee) which might be less effective for overseeing and not meeting applicable independence definitions. Also, when the audit committee do not meet regularly it can have an impact on improving transparency, competence and confidence on the financial expertise of non-executive independence directors in both small and large business. In addition, the results of Table 3 also indicate the relationship between board size and audit quality is negative with the level of 0.10 . Company size variable is positive to audit quality at the 0.01 level of significance. The relationship between the return on assets (ROA) and audit quality is negative but not significant $(p>0.10)$. The results of audit committee meetings have revealed positive insignificant relationship between the frequency of audit committee meetings and audit quality $(p>0.10)$. For cash flow results, there is a positive insignificant relationship between cash flow and audit quality ( $p>10)$. Finally, the results have indicated that the relationship between leverage and audit quality was negative with significant level of 0.05 .

\section{References}

Abbott, L. J, Parker, S. \& Peters, G. P. (2004). Audit committee characteristics and restatement. Auditing: A Journal of Practice and Theory, 3(1), 69-87.

Abbott, L. J., Parker, S., \& Peters, G. F. (2004). Audit committee characteristics and restatements. Auditing: A Journal of Practice \& Theory, 23(1), 69-87.

Abbott, L. J., \& Parker, S. (2000). Auditor selection and audit committee characteristics. Auditing: A Journal of Practice \& Theory, 19(2), 47-66.

Abbott, L. J., \& Parker, S. (2000). Auditor selection and audit committee characteristics. Auditing: A journal of practice \& theory, 19(2), 47-66.

Abbott, L. J. \& Parker, S. (1999). Audit committee characteristics and auditor selection: evidence from auditoswitches. Working paper. University of Memphis.

Abu Bakar, N., Rahman, A., \& Rashid, H. (2005). Factors influencing auditor independence: Malaysian loan officers' perceptions. Managerial Auditing Journal, 20(8), 804-822.

Adegbite, E. (2015). Good corporate governance in Nigeria: Antecedents, propositions and peculiarities. International Business Review, 24(2), 319-330.

Ahunwan, B. (2003). Globalization and corporate governance in developing countries: A micro analysis of global corporate interconnection between developing African countries and developed countries. Ardsley.

Al-Matari, Y. A., Al-Swidi, A. K., Fadzil, F. H. B., Fadzil, H., \& Al-Matari, E. M. (2012). Board of directors, audit committee characteristics and the performance of Saudi Arabia listed companies. International Review of Management and Marketing, 2(4), 241.

Al-Mudhaki, J., \& Joshi, P. L. (2004). The role and functions of audit committees in the Indian corporate governance: Empirical findings. International Journal of Auditing, 8(1), 33-47.

Ameer, R., Ramli, F. \& Zakaria, H. (2010). A new perspective on board composition and firm performance in an emerging market. Corporate Governance, 10(5), 647-661.

Anderson, R. C., Mansi, S. A., \& Reeb, D. M. (2004). Board characteristics, accounting report integrity, and the cost of debt. Journal of Accounting and Economics, 37(3), 315-342.

Balakrishnan, K., Billings, M. B., Kelly, B., \& Ljungqvist, A. (2014). Shaping liquidity: On the causal effects of voluntary disclosure. the Journal of Finance, 69(5), 2237-2278.

Bassett, L. (1998). Putting board evaluation to work. Corporate Board, 19(109), 20.

Behn, B. K., Carcello, J. V., Hermanson, D. R., \& Hermanson, R. H. (1997). The determinants of audit client satisfaction among clients of big 6 firms. Accounting horizons, $11(1), 7$. 
Bonn, I. (2004). Board structure and firm performance: Evidence from Australia. Journal of Management and Organisation, $10(1), 14-24$.

Bronson, S. N., Carcello, J. V., \& Raghunandan, K. (2006). Firm characteristics and voluntary management reports on internal control. Auditing: A Journal of Practice \& Theory, 25(2), 25-39.

Bronson, S. N., Carcello, J. V., Hollingsworth, C. W., \& Neal, T. L. (2009). Are fully independent audit committees really necessary?. Journal of Accounting and Public Policy, 28(4), 265-280.

Brown, A.M. (2004). The financial milieu of the IASB and AASB. 4th Asia Pacific Interdisciplinary Research in Accounting Conference, 4-6 July.

Bryan, D., Liu, M.H.C. \& Tiras, S.L. (2004). The influence of independent and effective audit committees on earnings quality. working paper, State University of New York, Buffalo, NY.

Carcello, J., \& T. Neal. (2000). Audit committee composition and auditor reporting. The Accounting Review, 75, 453-467.

Carcello, J., \& T. Neal. (2003). Audit committee characteristics and auditor dismissals following "'new" going- concern reports. The Accounting Review, 78, 95- 117.

Cheng, S. (2008). Board size and the variability of corporate performance. Journal of Financial Economics, 87(1), 157176.

Dalley, P. J. (2003). Public company corporate governance under the Sarbanes-Oxley Act of 2002. Okla. City UL Rev., 28, 185.

Davidson III, W. N., Xie, B., \& Xu, W. (2004). Market reaction to voluntary announcements of audit committee appointments: The effect of financial expertise. Journal of Accounting and Public Policy, 23(4), 279-293.

Deakin, S., \& Konzelman, S. (2004). Learning from Enron. Corporate Governance, 12(2), 134-142.

Deangelo, L. E. (1981). Auditor size and audit quality. Journal of Accounting and Economics, 3(3), $183-199$.

DeFond, M. L. (1992). The association between changes in client firm agency costs and auditor switching. Auditing, 11(1), 16.

DeFond, M. L., \& Francis, J. R. (2005). Audit research after sarbanes-oxley. Auditing: A Journal of Practice \& Theory, 24(s-1), 5-30.

DeFond, M. L., Hann, R. N., \& Hu, X. (2005). Does the market value financial expertise on audit committees of boards of directors?. Journal of Accounting Research, 43(2), 153-193.

DeZoort, F. T., \& Salterio, S. E. (2001). The effects of corporate governance experience and financial-reporting and audit knowledge on audit committee members' judgments. Auditing: A Journal of Practice \& Theory, 20(2), 31-47.

DeZoort, F. T., Hermanson, D. R., \& Houston, R. W. (2003). Audit committee support for auditors: The effects of materiality justification and accounting precision. Journal of Accounting and Public Policy, 22(2), 175-199.

Dhaliwal, D. A. N., Naiker, V. I. C., \& Navissi, F. (2010). The association between accruals quality and the characteristics of accounting experts and mix of expertise on audit committees. Contemporary Accounting Research, 27(3), $787-827$.

Duff, A. (2004). AUDITQUAL: Dimensions of Audit Quality. Institute of Chartered Accountants of Scotland: Edinburgh.

Eichenseher, J. W., \& Shields, D. (1985). Corporate director liability and monitoring preferences. Journal of Accounting and Public Policy, 4(1), 13-31.

Eisenberg, T., Sundgren, S., \& Wells, M. T. (1998). Larger board size and decreasing firm value in small firms1. Journal of financial economics, 48(1), 35-54.

Fama, E. F., \& Jensen, M. C. (1983). Separation of ownership and control. The journal of law and Economics, 26(2), 301325.

Fodio, M. I., Ibikunle, J., \& Oba, V. C. (2013). Corporate governance mechanisms and reported earnings quality in listed Nigerian insurance firms. International Journal of Finance and Accounting, 2(5), 279-286.

Francis, J. R., \& Krishnan, J. (1999). Accounting accruals and auditor reporting conservatism. Contemporary Accounting Research, 16(1), 135-165.

Francis, J.R., (2004). What do we know about audit quality? The British Accounting Review, 36(4), 345-368.

Gerdes, L. (2009, September 14). The best places to launch a career. Business Week, 32- 39.

Gottschalk, P. (2011). Prevention of white-collar crime: The role of accounting.

Gul, Ferid A., Hai Y., Teoh, Beer Andrew H.,, and Schelluch P. (1994). Theory and Practice of Australian Auditing. Third Edition, Nelson, an International Thomson Publishing Company, Australia.

Hoechle, D. (2007). Robust standard errors for panel regressions with cross-sectional dependence. Stata Journal, $7(3), 281$.

Hutchinson, M., Mack, J., \& Plastow, K. (2015). Who selects the 'right'directors? An examination of the association between board selection, gender diversity and outcomes. Accounting \& Finance, 55(4), 1071-1103.

International Auditing \& Assurance Standards Board. (2011). Audit Quality: An IAASB perspective. New York.

Jaime, S., \& Michael, S. W., (2013). Bringing darkness to light: The influence of auditor quality and audit committee expertise on the timeliness of financial statement restatement disclosures. Auditing: A Journal of Practice \& Theory, $32(1), 221-244$.

Cohen, J. R., Gaynor, L. M., Krishnamoorthy, G., \& Wright, A. M. (2011). The impact on auditor judgments of CEO influence on audit committee independence. Auditing: A Journal of Practice \& Theory, 30(4), 129-147.

Jensen, M. C. (1993). The modern industrial revolution, exit and the failure of internal control systems. Journal of Finance, $48(3), 831-880$

Jensen, M., \& Meckling, W. (1976). Theory of the firm: Managerial behavior, agency costs and ownership structure. Journal of Financial Economics, 3(4), 305-360. 
Kent, P., Routledge, J. \& Stewart, J. (2010). Innate and discretionary accruals quality and corporate governance. Accounting and Finance, 50, 171-195.

Nicholson, G. J., \& Kiel, G. C. (2004). A framework for diagnosing board effectiveness. Corporate Governance: An International Review, 12(4), 442-460.

Krishnan, G. V., \& Visvanathan, G. (2008). Does the SOX definition of an accounting expert matter? The association between audit committee directors' accounting expertise and accounting conservatism. Contemporary Accounting Research, 25(3), 827-858.

Krishnan, J. (2005). Audit committee quality and internal control: An empirical analysis. The accounting review, 80(2), 649-675.

Lee, T., \& Stone, M. (1995). Competence and independence: the congenial twins of auditing?. Journal of Business Finance \& Accounting, 22(8), 1169-1177.

Lin, J. W., Li, J. F., \& Yang, J. S. (2006). The effect of audit committee performance on earnings quality. Managerial Auditing Journal, 21(9), 921-933.

Lo, A. W., Wong, R. M., \& Firth, M. (2010). Can corporate governance deter management from manipulating earnings? Evidence from related-party sales transactions in China. Journal of Corporate Finance, 16(2), 225-235.

Louis, H. (2005). Acquirers' abnormal returns and the non-Big 4 auditor clientele effect. Journal of Accounting and Economics 40(1-3), 75-99.

Mautz, R. K., \& Sharaf, H. (1961). The Philosophy of Auditing. American Accounting Association.

Mautz, R.K., \& Neumann, F.L. (1970). Corporate audit committees. In S. Turley and M. Zaman, (2004). The corporate governance effects of audit committees. Journal of Management \& Governance, 8(3), 305-332.

McDaniel, L., Martin, R. D., \& Maines, L. A. (2002). Evaluating financial reporting quality: The effects of financial expertise vs. financial literacy. The accounting review, 77(s-1), 139-167.

McDonald, M. L., \& Westphal, J. D. (2013). Access denied: Low mentoring of women and minority first-time directors and its negative effects on appointments to additional boards. Academy of Management Journal, 56(4), 1169-1198.

Palmrose, Z-V. (1988). An analysis of auditor litigation and audit service quality. The Accounting Review, 63, 55-73.

PricewaterhouseCoopers (1999). Audit Committees: Best Practices for Protecting Shareholders' Interest, New York, NY.

PricewaterhouseCoopers (2002). Mandatory Rotation of Audit Firms: Will It Improve Audit Quality? PricewaterhouseCoopers LLP, NewYork.

Raheja, C. G. (2005). Determinants of board size and composition: A theory of corporate boards. Journal of financial and quantitative analysis, 40(2), 283-306.

Reichelt, K. J., \& Wang, D. (2010). National and office-specific measures of auditor industry expertise and effects on audit quality. Journal of Accounting Research, 48(3), 647-686.

Sarbanes Oxley (SOX) Act (2002).Retrieved March21,2011

SEC (2003). Disclosure Required by Sections 406 and 407 of the Sarbanes-Oxley Act of 2002, Release Nos 33-8177; 3447235, Securities and Exchange Commission, Washington, DC.

Sharma, V., Naiker, V., \& Lee, B. (2009). Determinants of audit committee meeting frequency: Evidence from a voluntary governance system. Accounting Horizons, 23(3), 245-263.

Skinner, D. J., \& Srinivasan, S. (2012). Audit quality and auditor reputation: Evidence from Japan. The Accounting Review, $87(5), 1737-1765$.

Smith Committee, (2003). Audit Committee Combined Code Guidance. Financial Reporting Council. London.

Sun, J. (2013). Auditor industry specialization, board governance, and earnings management. Managerial Auditing Journal, $28(1), 45-64$

Teoh, S. H., \& Wong, T. J. (1993). Perceived auditor quality and the earnings response coefficient. Accounting Review, 68(2), 346-366.

Treadway Commission. (1987). Report on the National Commission on Fraudulent Financial Reporting. Committee of Sponsoring Organizations, New York.

Vicknair, D., Hickman, K., \& Carnes, K. C. (1993). A note on audit committee independence: Evidence from the NYSE on" grey" area directors. Accounting Horizons, 7(1), 53-57.

Watts, R., \& Zimmerman, J. (1981). The markets for independence and independent auditors. Unpublished manuscript (University of Rochester, Rochester, NY).

Wolnizer, P. W. (1995). Are audit committees red herrings? Abacus, 31 (March), 45-66.

Xie, B., Davidson III, W. N., \& DaDalt, P. J. (2003). Earnings management and corporate governance: the role of the board and the audit committee. Journal of corporate finance, 9(3), 295-316.

Zona, F., Zattoni, A., \& Minichilli, A. (2013). A contingency model of boards of directors and firm innovation: The moderating role of firm size. British Journal of Management, 24(3), 299-315.

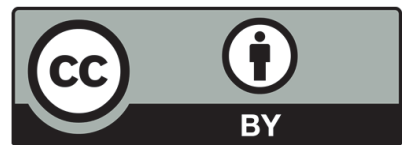

(C) 2019 by the authors; licensee Growing Science, Canada. This is an open access article distributed under the terms and conditions of the Creative Commons Attribution (CC-BY) license (http://creativecommons.org/licenses/by/4.0/). 